\title{
Construction Waste and its Distribution in Iraq: An Ample Review
}

\author{
Maytham Kadhim Obaid ${ }^{*}$, Ismail Abdul Rahman ${ }^{1}$, Intidhar Jabir Idan² and Sasitharan Nagapan ${ }^{1}$ \\ ${ }^{1}$ Faculty of Civil Engineering and Environment \\ Universiti Tun Hussein Onn Malaysia, 86400 Parit Raja, Malaysia; abuthar210@gmail.com \\ 2Department of Environmental Engineering, Faculty of Engineering, University of Babylon, Babylon, Iraq
}

\begin{abstract}
Because of the economic evolution and advancement of the construction industry observed by many countries, the critical requirement for utilizing contemporary potentials in it is to construct taller and deeper buildings. On the other hand, the problems that rise with the similar capacity is the generation of millions of tons of construction waste each year. Such generation of construction waste causing many landfilling and environment problems in the world. Through the last few decades, the rapid development of construction industry has been also observed in Iraq. Such rapid development causes huge amount of construction waste also and causing not only landfilling problems but also effects to environment. In this research work, review has been taken to emphasize on construction waste. Almost 51 latest and critical research papers and web blogs has been reviewed. On the basis of reviewed literature in this research work, it is observed that no any standards have been set for disposing off the construction waste at Government level. Also, many non-government companies are working to construct proper lands for disposing off the construction waste. But still, the union of Iraqi Contractors and Engineer League must symposium on construction waste and designed better plans to manage waste and disposing off construction debris.
\end{abstract}

Keywords: Amount and Distribution, Construction Waste, Construction Waste Management, Construction Waste types, Sources

\section{Introduction}

The progression in construction activities in the course of recent decades has brought about a parallel increment in the quantity of generating construction waste. This development, combined with deficiencies in landfill space, especially in urban zones, has turned out to be a difficult stress or to the environment ${ }^{1,2}$. The construction industry shows an important job in improving the worth of the built environment, but its activities also influence on the extensive environment in various means, including waste generation. Presently, world cities generate around 1.3 billion tons of construction waste every year. This quantity is relied upon to increment to 2.2 billion tons by 2025. Waste generation amounts will further than double over the next twenty years in developing countries ${ }^{3}$. This signifies a momentous growth in per capita waste generation proportions from 1.2 to $1.42 \mathrm{~kg}$ per person per day in the following fifteen years. Nonetheless, worldwide averages are extensive approximations merely as proportions differ noticeably by region, country, city, and even within cities. According to the European Commission statics, the total volume of Construction and Demolition (C\&D) waste produced in 2008 was about 890 million tons ${ }^{4}$. In developed countries, reusing of C\&DW waste is controlled by law and policy such that the reusing proportions have extreme exceeded $90 \%$. In Australia, nearly $90 \%$ of such waste was reused ${ }^{5}$, Japan's reusing rate is $99.5 \%$ in $2012^{6}$ and Singapore has revealed the maximum reusing proportion of $99.9 \%$. Malaysia's C\&DW retrieval proportion observed at not as much of as $50 \%{ }^{8}$. In Iraq there are a few previous studies on waste management in construction projects, like ${ }^{9-11}$ focused on estimate the volume of (C\&D) in construction sites. Though the activity has now move in a decay stage, because of the economic recession and the variation in the construction progression, difficulties instigated by such waste, or reasonably, by its supervision essentials to be addressed and considered in depth ${ }^{12}$. 
Higher growth in population, rapid growth in economic, increasing discretely earnings and different clashes has directed to deteriorating waste management challenges in Iraq. Iraq is expected to generate 31,000 tons of solid waste along with construction waste each day by per capita waste generation surpassing $1.4 \mathrm{~kg}$ per day. Additionally, many illegal landfills for dumping of the waste including C\&D waste reported and shown in Figure $1^{13}$ and Table $1^{14}$. Rapid increment in waste generation is setting great tension on Iraqi waste management organizations which have deeply smashed following years of clash and mismanagement. Without present day and productive waste dealing with and transfer framework the majority of the wastes are arranged in unapproved landfills crosswise over Iraq, with almost no apprehension for both environment and human health. Impulsive fires, groundwater pollution, surface water contamination and higher amount of greenhouse gas emissions have been the symbols of Iraqi landfills ${ }^{13}$.

Table 1 shows total 597 landfills until 2017, having 163 unapproved and 73 approved environmentally in the year 2015, but the trend decline trend in 2017 as compared to year 2016 for the approved and unapproved landfills. This is alarming situation to worsen the management of the waste in Iraq. However, for regular and non-regular transformational stations, the situation is different and showing an improvement for the waste management. It is mainly because of the lack of studies, research and developing coding standards related to the environmentally cleaning services sector to develop a sound waste management mechanism, also the geographical area of the cities and their horizontal extension, which is not commensurate with what exists from effort equipment and workers.

Iraq is a developing country and threatened by the construction waste challenges which haveled to an illegitimate waste that causing environmental pollution and, moreover, increasestheprojectbudget. Design, transportation, materials handling and storage are most important influential exercises in construction waste generation ${ }^{15,16}$. These exercises would exhaust time and energy without enhancing the customer, in this manner, causing in construction materials waste, interruption in project finishing time and performance of ineffective operations. All these challenge can aggravate if not addressed appropriately so in this work, the detailed review study on construction waste in Iraq is presented. In this review work, many latest and critical research papers and official and non-official web blogs were also reviewed to provide up-to-date information related to the subjected area. Construction waste, its types, sources of it, its waste and distribution presented and argued in an up-to-best manner in this review work. On the basis of reviewed stuff in this work, some conclusions and suggestions also presented but more than that some future studies also found which can be beneficial to the beginners in this subjected area.

\section{Solid Waste}

Solid waste is a comprehensive expression which contains the undesirable or unusable solid materials obtained from industrial, residential and commercial exercises in a particular zone. Solid waste can be categorized as per its source (construction domestic, commercial, industrial and institutional); as per impending of exposure from it (radioactive, flammable, toxic, non-toxic, infectious, etc.); also as per solid waste substances (glass, plastic paper, organic material, metal, etc. $)^{17}$. However; there are different types of solid waste ${ }^{18}$ as shown in Figure 2:

- Organic waste: waste from preparation of food, market places, etc.

- Combustibles: paper, wood, dried leaves, packaging for relief items, etc.

- Non-combustibles: metal, tin cans, bottles, stones, etc.

- Ashes/dust: residue from fires used for cooking.

- Bulky waste: tree branches, tiers, etc.

- Dead animals: carcasses of domestic animals and livestock.

- Hazardous waste: oil, battery acid, medical waste.

- Construction waste: roofing, rubble, broken concrete, etc.

Table 1. Environmental Statistics for Iraq - Municipal Services 2015, 2016, $2017^{14}$

\begin{tabular}{|l|c|c|c|c|c|c|}
\hline $\begin{array}{l}\text { No. of } \\
\text { Landfill }\end{array}$ & Year & $\begin{array}{c}\text { Environm-entally } \\
\text { Approved }\end{array}$ & $\begin{array}{c}\text { Environmental-ly } \\
\text { Unapproved }\end{array}$ & $\begin{array}{c}\text { Regular Transformational } \\
\text { Stations }\end{array}$ & $\begin{array}{c}\text { Non-Regular } \\
\text { Transformer Stations }\end{array}$ & $\begin{array}{c}\text { Random Dump } \\
\text { Locations }\end{array}$ \\
\hline 236 & 2015 & 73 & 163 & 30 & 78 & 235 \\
\hline 156 & 2016 & 112 & 44 & 42 & 23 & 34 \\
\hline 205 & 2017 & 57 & 148 & 59 & 23 & 53 \\
\hline
\end{tabular}



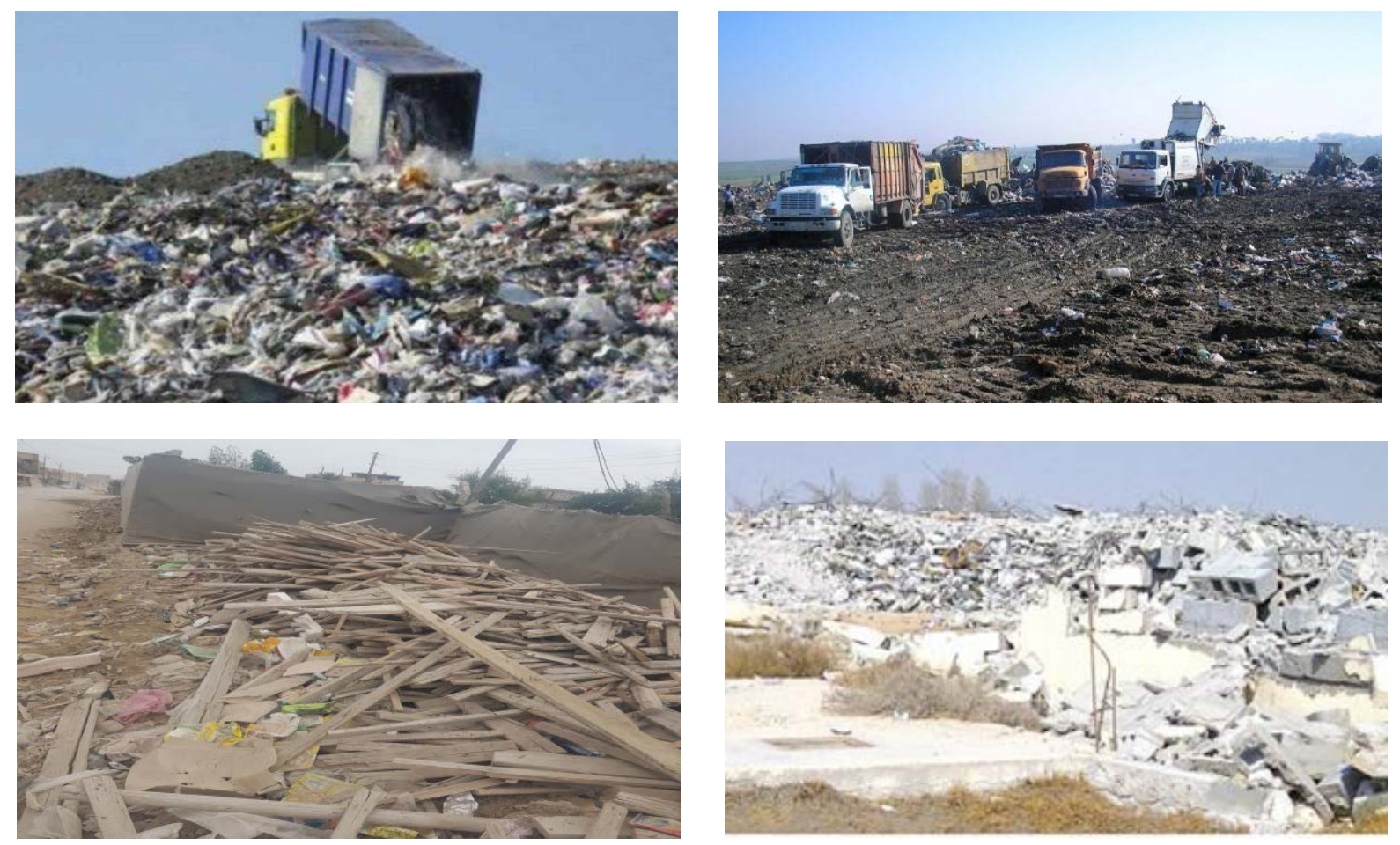

Figure 1. Illegal dumped of waste including C\&D waste [13].

Iraq with a population more than 32 Million in 2013 generated 31,000 tons per day of solid waste ${ }^{19}$. Baghdad is considered the capital city with a population density about 7 million and generated more than 2.5 Million Tons of solid waste annually ${ }^{19}$. As per $^{20,21}$ wastes generation, types and sources in Iraq as shown in Table 2.

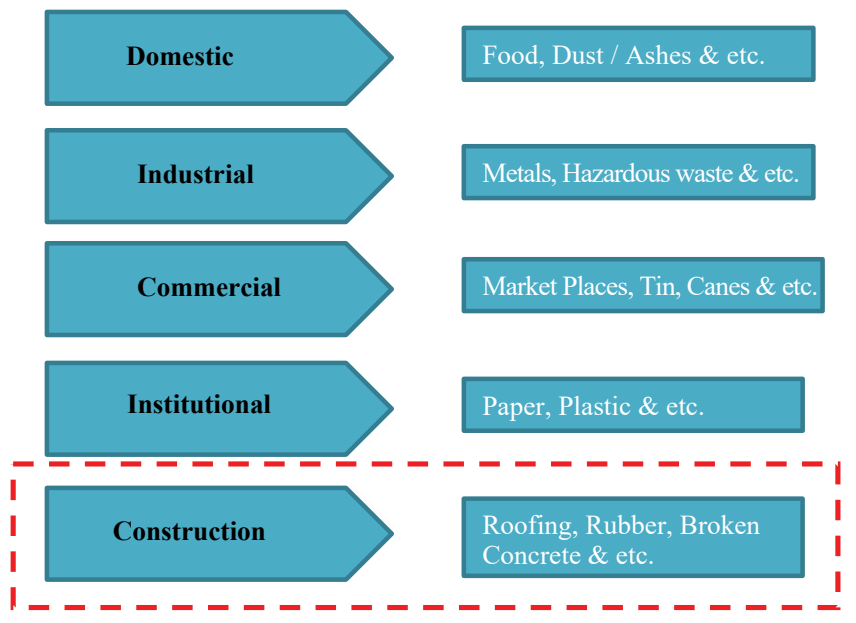

Figure 2. Solid waste classification [18].

\section{Construction Waste}

Construction waste have no any general definition and can be discussed in broad spectrum as Ortiz et al., 2010 defined it as whichever material or by-product of humanoid or industrial operation that has no particular value $^{22}$, such definition was also supported by ${ }^{23}$. Also Llatas, defined the construction waste is the general word referred to any material yields from construction places, demolition of structures, or of a combination of both ${ }^{24}$. As per ${ }^{25}$ constructions waste is characterized as the contrast between the esteem and amount of materials acquired and the amount of material utilized as indicated and precisely. Construction waste have no any general definition and can be discussed in broad spectrum as Ortiz et al., 2010 defined it as whichever material or by-product of humanoid or industrial operation that has no particular value $22,26,27$. In other words, it is defined as "any losses produced by activities that generate direct or indirect costs but do not add any value to the product from the point of view of the client" ${ }^{28}$. Moreover, a clear comprehension about 
Table 2. Wastes generation, types and sources in Iraq $q^{20,21}$

\begin{tabular}{|c|c|c|}
\hline Type & Source & Waste Components \\
\hline Waste from House & Buildings and Houses & $\begin{array}{l}\text { Food, Plastics, Cardboard, Leather, Textiles, } \\
\text { Wood, Glass, Garden Waste, Ash, Metals, } \\
\text { Electronic Devices, Special Waste, Oils, Batteries, } \\
\text { Hazardous Waste, Tires. }\end{array}$ \\
\hline Waste from Industries & $\begin{array}{l}\text { Small and Medium Manufacturing } \\
\text { industries, power plants, chemical plants. }\end{array}$ & $\begin{array}{l}\text { Food stuffs, Destruction waste, Household waste } \\
\text { products, Packaging, Construction waste, Non- } \\
\text { standard products, }\end{array}$ \\
\hline Waste from Commercial Area & $\begin{array}{l}\text { Hotels, stores, markets, restaurants, office } \\
\text { buildings }\end{array}$ & $\begin{array}{l}\text { Cardboard, Paper, Wood, Plastic, Glass, Food } \\
\text { residues, Metals }\end{array}$ \\
\hline Waste from Institutes & Government Buildings, Schools, Prisons, & Same as in waste from commercial area \\
\hline Waste from Hospitals & $\begin{array}{l}\text { Hospitals, Health Care Centers, medical } \\
\text { clinics, maternity centers }\end{array}$ & Non-Toxic waste containing of food and paper \\
\hline Waste from Construction & $\begin{array}{l}\text { Ongoing construction, restoration sites, } \\
\text { road repair, destruction of buildings }\end{array}$ & Concrete, Metals, Wood \\
\hline Waste from Municipal Activities & $\begin{array}{l}\text { Water treatment sites, parks, Street } \\
\text { cleaning, beaches etc. }\end{array}$ & $\begin{array}{l}\text { Street cleaning, garden waste, recreational and } \\
\text { parks areas waste. }\end{array}$ \\
\hline Waste from Agricultural & $\begin{array}{l}\text { Dairy plants, Orchards, waste of animal } \\
\text { slaughter, farms }\end{array}$ & Agricultural waste and musty food \\
\hline
\end{tabular}

the construction waste conception, it is compulsory to classify the types of construction waste in unlike perceptions.

Construction waste is a combination of extra materials produced through new construction, repair, and destruction of structures, bridges, roads, and entire further works linked to civil engineering ${ }^{29-31}$.

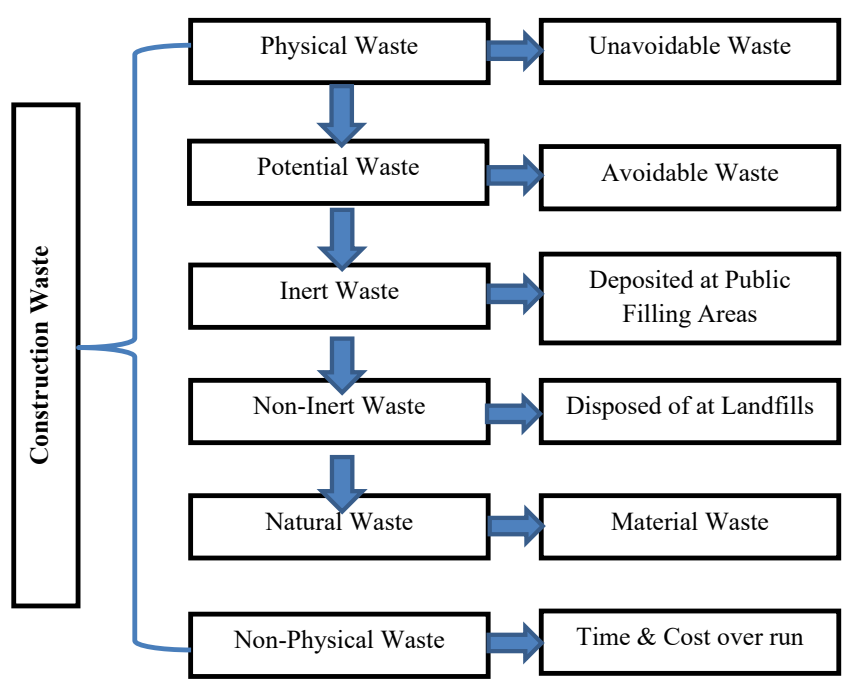

Figure 3. Construction waste classifications.

\section{Classification of Construction Waste}

As per ${ }^{32}$ constructions waste mainly categorized into two different groups: physical and non-physical wastes. While as per $^{25}$ the essential types of construction waste are natural, potential, inert, non-inert and physical wastes. However, in this work, the types of construction waste are discussed below and summarized in Figure 3 .

\subsection{Physical Construction Waste}

It is defined as "the waste which originates from construction, renovation and demolition actions including land excavation, civil and building construction, site clearance, roadwork, and building demolition and renovation" 33,34 . In simple definition, physical waste is acknowledged as the waste which can be detected practically at project site area. Physical waste contains enervation of construction materials, as they are irreparably broken and missing ${ }^{35,36}$. However; physical construction waste always transported from the project site to landfills ${ }^{37,38}$. On the other hand, it is categorized into 3-sub-groups: additional material loss, equipment operational time and man-hour overproduction $^{39}$. 


\subsection{Non-Physical Construction Waste}

Usually non-physical waste contains both time and cost overruns as its major forms and normally produced during construction activities. Work disturbances, waiting periods, deferments in execution and getting work authorizations, reworks and conductance of preventable works are major kinds of wastage of time ${ }^{37}$. While, cost overrun is considered as "cost increase" or "budget overrun". Cost overrun includes unexpected costs experienced in excess of the budgeted amounts ${ }^{40}$. Numerous authors have stated that both time and cost wastes can lead to the generation of waste material ${ }^{38}$. As like, Memon et.al stated that "non-physical waste includes undesired activities, which can cause the physical waste, such as rework, and unnecessary material movements"41.

\section{Source of Construction Waste Generation}

Construction waste has the following sources: overproduction, transportation, movement, substitution, inventories, waiting time, processing, production of defective products and others $\mathrm{s}^{25,42-45}$.

\section{Amount of C\&D waste}

As per the Central Statistics Organization (CSO) for 2016, 2017 and 2018, the C\&D waste and total solid waste generated for 2015, 2016 and 2017 are extracted as in Table 4.

These percentages of $C \& D$ waste over the total solid waste for the cities of Iraq are presented in Figures 4-6.

\section{Construction Waste and their Distribution}

For construction waste we mean waste from construction. They are solid waste, demolition, construction, extension, repair, demolition of buildings, buildings, roads, bridges, sewage outlets such as asphalt, concrete, brick, wood, glass, aluminum, iron, packaging, pipe insulation, wires. These wastes differ in structure, but the benefits of their reduction and reuse as well as recycling, if possible, for new applications gives additional efficiency.

Following quite a while of strife and global endorses a great part of the key common framework inside Iraq has fallen into deterioration, prompting an extensive

Table 3. Illustrates those sources attached with their descriptions $s^{25,42-45}$

\begin{tabular}{|c|c|}
\hline Source & Description \\
\hline Overproduction & $\begin{array}{l}\text { Represented by excessive quantities of materials to be produced than the intended / required quantity } \\
\text { which results in man-hours, materials and equipment wastage. }\end{array}$ \\
\hline Transportation & $\begin{array}{l}\text { Referred to the movements of construction materials in site. This type caused by lack of materials control } \\
\text { when transported due to usage of improper equipment and depraved situations of sequences adopted in site } \\
\text { resulted from lack of planning. }\end{array}$ \\
\hline Movement & $\begin{array}{l}\text { Related to unnecessary movements displaced by labors in construction site. This type resulted from poor } \\
\text { arrangement of works, ineffective work methods or inadequate equipment used. }\end{array}$ \\
\hline Substitution & $\begin{array}{l}\text { Referred to substitution of intended materials by expensive ones, employ qualified labors or sophisticated } \\
\text { equipment for simple works. }\end{array}$ \\
\hline Inventories & $\begin{array}{l}\text { Concerned with unnecessary / exaggerated inventories of construction materials that would be transformed } \\
\text { to waste due to inadequate storage conditions, deterioration, theft \& vandalism. }\end{array}$ \\
\hline Waiting time & $\begin{array}{l}\text { Represented by the idle time spent by the labors gang / equipment due to lack of materials flow and } \\
\text { synchronism }\end{array}$ \\
\hline Processing & $\begin{array}{l}\text { Referred to the nature of activity that consumes the intended materials which could be reduced to its lowest } \\
\text { rates by changing the technology adopted. }\end{array}$ \\
\hline $\begin{array}{l}\text { Production of } \\
\text { defective products }\end{array}$ & $\begin{array}{l}\text { Correlated to waste caused by the non-compliance of the final product / activity with the intended } \\
\text { specification / quality. This might result from lack of planning and control, deficiency of incorporation } \\
\text { between design and production, poor qualification of the team work, etc. }\end{array}$ \\
\hline Others & $\begin{array}{l}\text { Any other waste which dissimilar to the earlier defined wastes like: vandalism, burglary, accidents, } \\
\text { inclement weather, etc. }\end{array}$ \\
\hline
\end{tabular}


Table 4. C\&D waste generated between 2015,2016 and $2017^{14}$

\begin{tabular}{|c|c|c|c|c|c|c|}
\hline \multirow[b]{2}{*}{ City } & \multicolumn{2}{|l|}{2015} & \multicolumn{2}{|l|}{2016} & \multicolumn{2}{|l|}{2017} \\
\hline & $\begin{array}{l}\text { C\&D waste } \\
\text { (ton / year) }\end{array}$ & $\begin{array}{l}\text { Total waste } \\
\text { (ton / year) }\end{array}$ & $\begin{array}{l}\text { C\&D waste } \\
\text { (ton / year) }\end{array}$ & $\begin{array}{l}\text { Total waste } \\
\text { (ton / day) }\end{array}$ & $\begin{array}{l}\text { C\&D waste } \\
\text { (ton / year) }\end{array}$ & $\begin{array}{l}\text { Total waste } \\
\text { (ton / day) }\end{array}$ \\
\hline Baghdad Center & $583,890.5$ & $4,118,259$ & $3,500.8$ & $3,838,237.4$ & $59,766.4$ & $2,522,159.9$ \\
\hline Outskirts of Baghdad & $15,001.5$ & 321,273 & 95,201 & 634,245 & 117,424 & 680,777 \\
\hline Karbala & 214,255 & 563,633 & $436,950.4$ & $867,130.8$ & $331,769.6$ & $794,741.4$ \\
\hline Babil & $73,182.5$ & 347,298 & $356,308.2$ & $785,437.2$ & $186,884.8$ & $575,874,8$ \\
\hline Salah al-din & $22,520.5$ & 269,480 & 462,321 & 825,806 & $823,911.5$ & $1,556,554$ \\
\hline Maysan & $126,472.5$ & 645,284 & 93,568 & 430,123 & 46,364 & 401,919 \\
\hline Muthanna & 184,982 & 348,977 & $179,220.8$ & $357,869.8$ & $60,435.2$ & $219,077.2$ \\
\hline Wasit & 61,320 & 364,015 & 232,194 & 606,506 & 219,078 & 539,544 \\
\hline Qadisiyah & 134,247 & 452,345 & 167,080 & 579,244 & 236,712 & 554,659 \\
\hline Diyala & $26,243.5$ & 354,306 & 85,128 & 409,928 & $74,223.2$ & $440,158.2$ \\
\hline Anbar & not- recorded & not- recorded & not-recorded & not-recorded & $2,073,483$ & $2,954,364$ \\
\hline Kirkuk & $7,482.5$ & 377,155 & $99,297.6$ & $385,298.67$ & $86,412.8$ & $384,420.8$ \\
\hline Dhi Qar & 6,0663 & 226,997 & $80,924.8$ & $620,201.8$ & 95,707 & $701,822.5$ \\
\hline Najaf & $285,101.5$ & 902,098 & $341,587.7$ & $895,451.2$ & 490,947 & $1,168,301$ \\
\hline Ninewa & not- recorded & not recorded & not-recorded & Not-recorded & $3,210,299.4$ & $3,899,283.8$ \\
\hline Basrah & 433,547 & $1,647,647$ & $2,120,484$ & $3,310,214$ & $2,249,905.6$ & $3,276,539.6$ \\
\hline
\end{tabular}

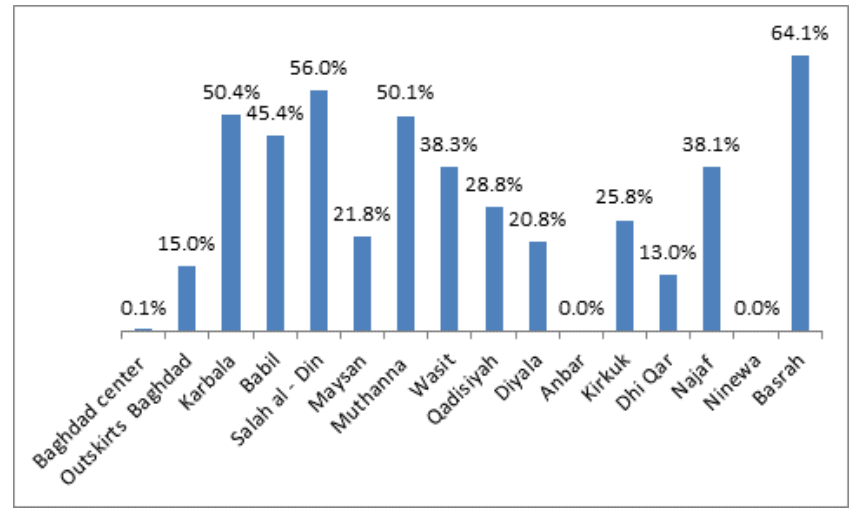

Figure 4. Percentage of C\&D waste compared to total waste of each city in Iraq for 2015.

decrease in the arrangement of fundamental and basic civil administrations. This is especially valid for waste and asset the executive's benefits that have seen long stretch of under development and deterioration ${ }^{46}$. In an outcome to such scenario in Iraq, a National Solid Waste Management Plan (NSWMP) was introduced in 2007, to get ready for the vital improvement of all parts of waste administration in the nation over the coming 20 years. Such NSWMP plan for Iraq was developed by association of international waste management experts.

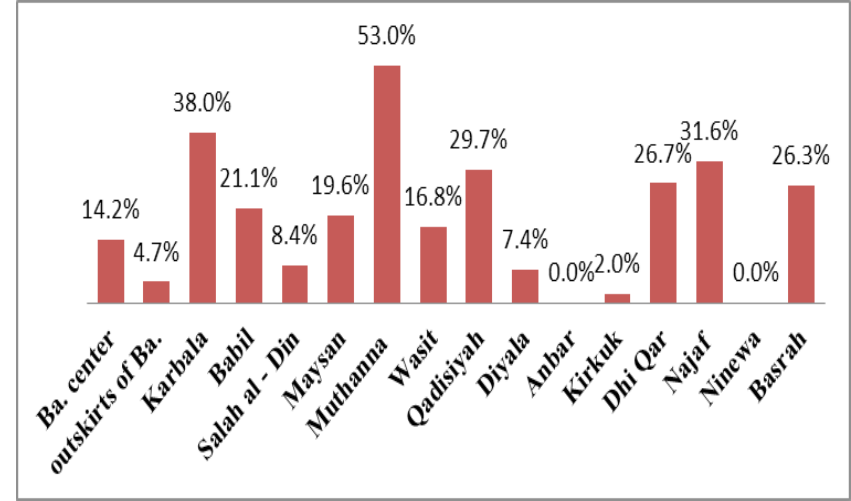

Figure 5. Percentage of C\&D waste compared to total waste of each city in Iraq for 2016.

The plan contains the suggestions for improvement and which clarifies the foundation for choices ${ }^{13}$. However; the majorly principles of NSWMP in Iraq are précised $a^{46}$ : Proximately principles and self-sufficiency, sustainable development, precautionary principles, producer responsibility, polluter pays principle, waste hierarchy and best practicable environmental option.

Generally, plan explains that 33 environmentally engineered landfills will be constructed in Iraq having 600 million m3 capacity in all 18 governorates in Iraq by 2027 . 


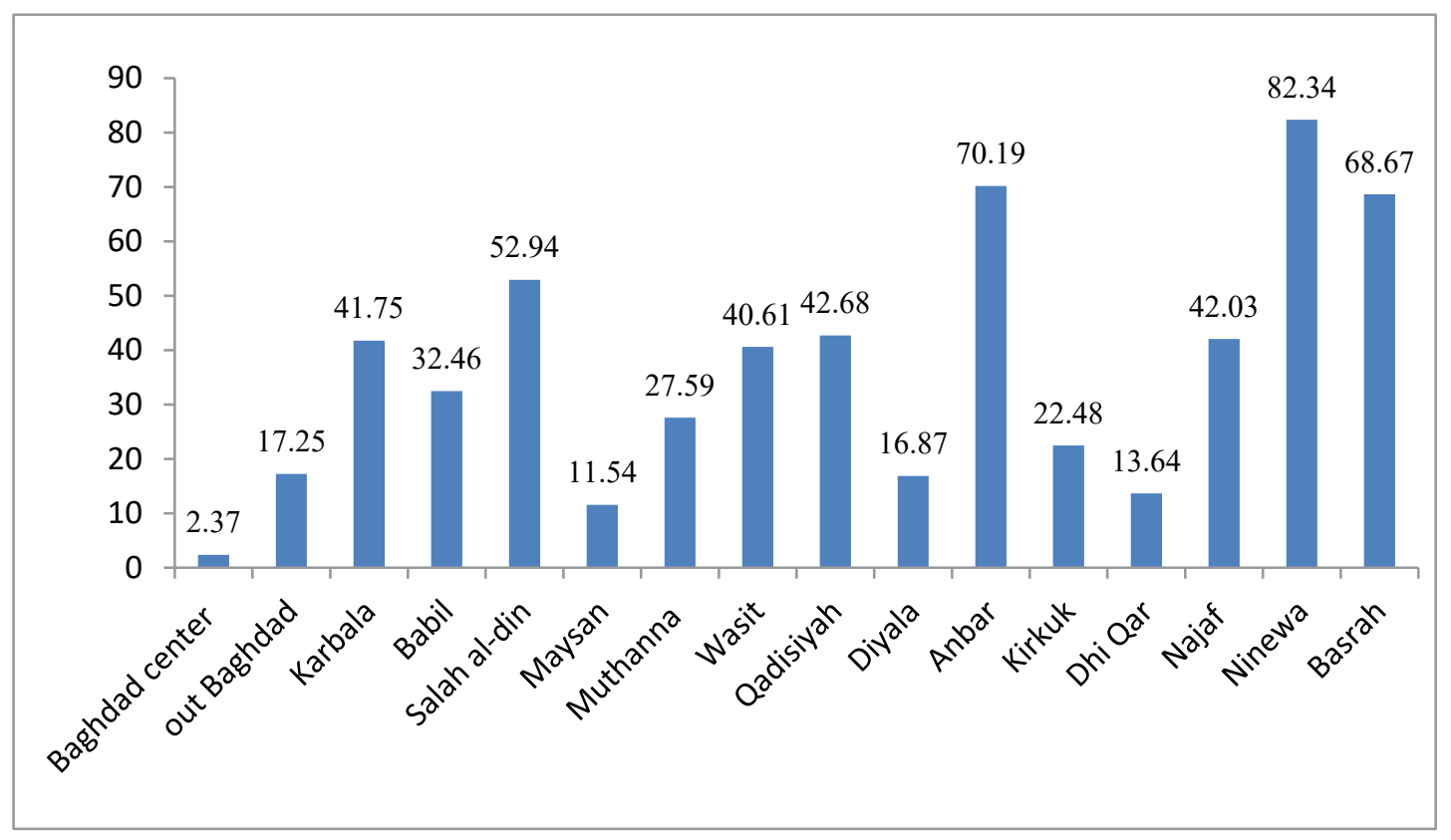

Figure 6. Percentage of C\&D waste compared to total waste of each city in Iraq for 2017.

The plan also emphasis on the collection, transportation, disposable, recycling and reuses system $^{47}$. In Iraq, Kirkuk was the first city to get productive outcomes from solid waste management program. Such solidwaste management program was initiated by the foreign funded agencies in 2005 to discover an environmentally harmless solution to the city's debris collection and disposal problem. This landfill is expanded on 48-acre and is located 10 miles south of Kirkuk. Furthermore, it has a predictable lifespan of 10-12 years and will achieve the both U.S. Environmental Protection Agency and European Union Landfill Directive standards ${ }^{48}$. Basra is the second city of Iraq where the first landfill was constructed as per international environmental standards. This landfill was fully funded from international aid. Solid waste management program in Basra was established by UNICEF and it will not only renovate proficient waste gathering organisms in the city but will also establish familiar "recycling schools" which helps in promoting environmental responsiveness in in the public in the city by initiation a movement to instruct the people about effective waste dumping procedures. UNICEF also developed Erbil's solid waste management master plan through the aid from the European Union. Finally, the solid waste management master plan for Dohuk Governorate was developed and finalized in June-2011 with the funding from UNICEF.

\section{Conclusion}

This research work is about reviewing the $\mathrm{C} \& \mathrm{D}$ waste in Iraq. In this review work, we; the authors review the latest and most critical research work related to the Iraq about subjected area. Furthermore; we highlighted the current challenges and problems due to C\&D waste and in continuous to it, briefly explain the C\&D waste, its types, sources and distribution in the Iraq. However; on the basis of review stuff in this research work we concluded that the construction materials waste has been considered as a main challenge in the construction industry which has significant effects on both of the proficiency of the industry and on the environmental effect of the construction developments. The construction industry is a significant component in overall economy. Also, the construction waste increase in the same proportion with the increment in the construction industry. Besides to it, less importance to waste reduction and poor management procedure led to generation of massive quantity of construction material waste. Furthermore, project cost deviancy and illegitimate landfill dumping are main difficulties in Iraqi construction industry, these problems are closely associated to construction waste ${ }^{32}$. Inadequate labors experience, resident engineer and technical staff and existence of several mistakes during project execution are considered as major causes beyond the high rates 
generated in privately construction projects ${ }^{27}$. The actual waste percentages of construction materials at the local scale at Karbala are more than the restrictions fixed by the Iraqi Ministry of Housing and Construction ${ }^{49}$. Local contracting companies don't appear to be alarmed about material waste hence they don't apply a systematic control of material usage ${ }^{50}$. Also there is no system applied in construction projects in Iraq for managing waste. The ways of dealing with types of waste generated in the construction projects of Iraq, are different according to nature of generated materials ${ }^{51}$.

In continuation to the conclusion of the research work, to understand the crucial importance for reducing the construction waste, we wish to express some recommendations for the Iraq Government and NonGovernment sectors as: all the concerned Government Ministries related to Housing and Building, Planning and Environment for setting up the regulations to minimize the construction waste, following the international rules for eco-environmentally and proper dispose-off the construction waste. Also, the Union of Iraqi Contractors to conduct symposiums to raise contractors' awareness using modern appropriate measures to lower down materials waste in the construction sites. In the last, the Iraqi Engineers League must have conducted symposiums to raise the awareness of the professional teams (designers, procurement committees, and site planning engineers) in the dilemma of construction material waste.

\section{Future Studies}

Construction waste is continually increasing due to everlasting need of new building and infrastructure development projects. This has developed one of the foremost environmental complications all over the world. As per the European Union Waste Strategy, construction waste is considered as one of the urgency waste streams. The construction industry shows important part in growth of economic and social advancement of the Iraq. But, construction industry also is fronting serious difficulties in the shape of construction waste generation and requires severe consideration and in seriousness to solve this problem. To solve such difficulties and challenges, the more important phase is to recognize the construction waste problem, reasons for generation and the effects of construction waste. A little research work on construction waste in Iraq is focused on quantifying the amount of the waste generated. However, it is still required to more work on this area and to identify the factors and causes which are contributing to the waste generation. On the basis of reviewed literature in this work, we wish to work out more to find the factors and check the contributions of such factors to the construction waste. Also, discover the remedies for reducing the influences of such factors for generating construction waste. Furthermore; the awareness must be spread through proper stream channels to the concerned for reducing the construction waste. Above than that, the authorities must design a waste management plan suitable for the execution environment in Iraqi construction sites and develop a waste disposal data system because of the acute demerit in the construction waste data base at local scale.

\section{References}

1. Alajeeli HKB, Al Kaabi SAM. A study of waste management reality in construction projects in Iraq. Wasit Journal of Engineering Science. 2016; 4(1):75-92.

2. Bakshana A, Srour I, Chehab G, and El-Fadel M. A field based methodology for estimating waste generation rates at various stages of construction projects. Resources, Conservation and Recycling. 2015; 100:70-80. https://doi. org/10.1016/j.resconrec.2015.04.002

3. Hoornweg D, Bhada-Tata P. What a waste a global review of solid waste management. Urban Development Series. 2012 Mar; 15.

4. European Commission. Eurostat statistics [Internet]. 2012. [cited 2019 Apr 1]. Available from:, http://epp.eurostat. ec.europa.eu/portal/page/portal/eurostat/home/.

5. CCANZ (Cement \& Concrete Assoc. of New Zealand). Best practice guide for the use of recycled aggregates in new concrete. CCANZ Technical Report, New Zealand [Internet]. 2011. [cited 2019 Apr 1]. Available from: <www.ccanz.org.nz/files/documents/ ad659c71-06cb-44b1-95dd-7b7350fdcd54/TR_14_ Recycled_Aggregates_in_New_Concrete_2013.pdf.

6. MLIT (Ministry of Land, Infrastructure, Transport and Tourism). White paper on land, infrastructure, transport and tourism in Japan 2014, Ministry of Land Infrastructure Transport and Tourism, Japan [Internet]. 2014. [cited 2019 Apr 1]. Available from: <www.mlit.go.jp/ common/001063075.pdf.

7. NEA (National Environment Agency). Waste statistics and overall recycling. National Environment Agency. Singapore [Internet]. [cited 2019 Apr 1]. Available from: www.nea. gov.sg/energy-waste/waste-management/waste-statisticsand-overallrecycling. 
8. UNCRD (United Nations Centre for Regional Development). 3R as an economic industry - next generation 3R solutions for a resource efficient society and sustainable tourism development in Asia and the Pacific. 6th Regional 3R Forum in Asia and Pacific, 16th-19th August, Malé, Maldives [Internet]. 2015. [cited 2019 Apr 1]. Available from: <www.uncrd.or.jp/content/documents/27516-3R Country-Report_Malaysia.pdf.

9. Al-Ajili HK. Proposed development of waste management in Iraq, Al-Nahrain University; 2010.

10. Qassem AA. Estimation and recycle of construction waste in Basrah Governorate. 2014; 14(1):2014.

11. Ghaleem SM, Nour AFA. Structural Waste Management; 2007.

12. Saez PV, Merino MD, Gonzlez AS, Amores CP. Best practice measures assessment for construction and demolition waste management in building constructions. Resources, Conservation and Recycling. 2013; 75:52-62. https://doi. org/10.1016/j.resconrec.2013.03.009

13. Alnajjar AY. Solid waste management scenario in Iraq, Middle East [Internet]. 2013. Available from: EcoNENA. http://www.ecomena.org/tag/solid-waste-management-iniraq.

14. Ministry of Planning - Central Statistics organization (CSO) The Republic of Iraq, Ministry of Planning, Central Bureau of Statistics, Department of Environment Statistics, Iraq Environmental Statistics [Internet]. Available from: www.cosit.gov.iq/.

15. Khudair LK. analytical study of the municipal services sector and its impact on the environmental aspects in the Governorates of Iraq for the Year 2015. Journal of the Professor, Issue of the Fifth Scientific Conference of 2017, Baghdad; 2017.

16. Bakshana A, Srour I, Chehab G, and El-Fadel M. A field based methodology for estimating waste generation rates at various stages of construction projects. Resources, Conservation and Recycling. 2015; 100:70-80. https://doi. org/10.1016/j.resconrec.2015.04.002

17. Femi F, Oluwole O. Management of municipal solid waste [Internet]. 2013. Available from: http://www.academia. edu/4254191/Management_of_Municipal_Solid_Waste.

18. Goorhuis M. Handbook of Recycling, Chapter 26 - Developments in collection of municipal solid waste, stateof-the-art for practitioners, analysts, and scientists; 2014. https://doi.org/10.1016/B978-0-12-396459-5.00026-X

19. Mostafa AS, Mohsin AA, Ali LN. Management of Solid Waste in Baghdad, Iraq. World Academy of Science, Engineering and Technology. International Journal of Environmental and Ecological Engineering. 2017; 11(7):700-4.

20. Khudair LK. Analytical study of the municipal services sector and its impact on the environmental aspects in Iraq's governorates for the Year 2015, Al-Ustad Magazine, Issue of the Fifth Scientific Conference of 2017, Baghdad; 2017. p. 321.

21. Musheb JM. The economics of waste recycling in iraq: wasted resources and lost opportunities. European Journal of Economics and Business Studies. 2018; 4(2):90-8. https://doi.org/10.2478/ejes-2018-0042

22. Ortiz O, Pasqualino JC, Díez G, Castells F. The environmental impact of the construction phase: An application to composite walls from a life cycle perspective. Resources, Conservation and Recycling. 2010; 54:832-40. https://doi.org/10.1016/j.resconrec.2010.01.002

23. Osmani M. Construction waste minimization in the UK: Current pressures for change and approaches. Procedia - Social and Behavioral Sciences. 2012; 40:37-40. https://doi.org/10.1016/j.sbspro.2012.03.158

24. LLATAS C. Methods for estimating construction and demolition (C\&D) waste. University of Seville, Spain; 2013. https://doi.org/10.1533/9780857096906.1.25

25. Akhund MA, Memon AH, Memon NA, Ali TH, KhosoAR. Exploring types of waste generated: A study of construction industry of Pakistan. MATEC Web of Conferences; 2019. https://doi.org/10.1051/matecconf/201926605011

26. Amasuomo E, Baird J. The concept of waste and waste management. Journal of Management and Sustainability. 2016; 6(4):88. https://doi.org/10.5539/jms.v6n4p88

27. Khaleel TAM, Al-Zubaidy AM. Quantification of construction waste generated in construction projects of Iraq. Global Journal of Engineering Science and Researches. 2017:87-92.

28. Abdul-Rahman I, Memon AH, Abd. Karim AT. Significant factors causing cost overruns in large construction projects in Malaysia. Journal of Applied Sciences. 2013; 13(2):286-93. https://doi.org/10.3923/jas.2013.286.293

29. Cheng JC, Ma LY. A BIM-based system for demolition and renovation waste estimation and planning. Waste Management. 2013; 33:1539-51. https://doi.org/10.1016/j. wasman.2013.01.001. PMid:23490358

30. U.S Environmental Protection Agency - (EPA), Construction \& Demolition (C\&D) Materials [Internet]. 2008 Jan 13. [cited ]. Available from: http://www.epa.gov/ epawaste/conserve/imr/cdm/.

31. Hassan SH, Ahzahar N, Fauzi MA, Eman J. Waste Management issues in the northern region of Malaysia. Procedia - Social and Behavioral Sciences. 2012; 42:175-81. https://doi.org/10.1016/j.sbspro.2012.04.179

32. Khaleel T, Al-Zubaidy A. Major factors contributing to the construction waste generation in building projects of Iraq. MATEC Web of Conferences 162, 02034; 2018. https://doi.org/10.1051/matecconf/201816202034

33. Poon CS, Yu AT, Wong A, Yip R. Quantifying the impact of construction waste charging scheme on construction 
waste management in Hong Kong. Journal of Construction Engineering and Management. 2013; 139(5):466-79. https://doi.org/10.1061/(ASCE)CO.1943-7862.0000631

34. Foo LC, Rahman IA, Asmi A, Nagapan S, Khalid KI. Classification and quantification of construction waste at housing project site. International Journal of Zero Waste Generation. 2013; 1(1):1-4.

35. Fadiya OO, Georgakis P, Chinyio E. Quantitative analysis of the sources of construction waste. Journal of Construction Engineering; 2014. https://doi.org/10.1155/2014/651060

36. Udawatta DN. Integrating the dancers with the dance: A study of project culture and waste management in the Australian construction industry. Doctoral dissertation, University of South Australia; 2015.

37. Teo MM, Loosemore M. A theory of waste behaviour in the construction industry. Construction Management and Economics. 2001; 19(7):741-51. https://doi. org/10.1080/01446190110067037

38. Kulatunga U, Amaratunga D, Haigh R, Rameezdeen R. Attitudes and perceptions of construction workforce on construction waste in Sri Lanka. Management of Environmental Quality: An International Journal. 2006; 17(1):57-72. https://doi.org/10.1108/14777830610639440

39. Sasitharan N, Ismail AR, Ade A. Construction waste management: Malaysian perspective. In The International Conference on Civil and Environmental Engineering Sustainability, IConCEES; 2012.

40. Shanmugapriya S, Subramanian K. International Journal of Emerging Technology and Advanced Engineering. 2013; 3:734-40.

41. Memon AH, Abdul-Rahman I, Memon I. Life Science Journal. 2014; 11:417-24.

42. Amasuomo E, Baird J. The concept of waste and waste management. Journal of Management and Sustainability. 2016; 6(4):88. https://doi.org/10.5539/jms.v6n4p88
43. Foo LC, Rahman IA, Asmi A, Nagapan S, Khalid KI. Classification and quantification of construction waste at housing project site. International Journal of Zero Waste Generation. 2013; 1(1):1-4.

44. Adewuyi TO, Odesola IA. Factors affecting material waste on construction sites in Nigeria. Journal of Engineering and Technology. 2015; 6(1):82-99.

45. Al-Agele HKB, Al-Kaabi SA. Identification of key factors affecting waste management in life cycle of the construction project by using Delphi Technique. Journal of Engineering. 2016; 22(7):19-34.

46. Knowles JA. National solid waste management plan for Iraq. Waste Management \& Research. 2009; 27:322-7. https:// doi.org/10.1177/0734242X09104129. PMid:19470543

47. Waste collection, management and disposal in the Middle East. RSK Group Limited [Internet]. [cited 2019 Apr 09]. Available from: https://www.rsk.co.uk/images/technicallibrary/service-sheets/SS0265.pdf.

48. Alnajjar AY. Waste management in Iraq. Bio energy consult. Powering clean energy future [Internet]. 2019. [cited 2019 Apr 09]. Available from: https://www.bioenergyconsult. com/waste-iraq/.

49. Khaled ZSM, Alshathr BS, Hadi AH. Investigation of material waste incurred in the construction projects at Karbala province IN IRAQ. International Journal of Civil Engineering and Technology. 2014; 5(10):58-73.

50. Sajjad HKBA, Al Kaabi AM. A study of waste management reality in construction projects in Iraq. Wasit Journal of Engineering Science. 2016; 4(1):75-92.

51. Al-Ansari N, Pusch R, Knutsson S. Suggested landfill sites for hazardous waste in Iraq. Natural Science. 2013; 5(4):463-77. https://doi.org/10.4236/ns.2013.54060 